\title{
Psychological capital, job demands and organisational commitment of employees in a call centre in Durban, South Africa
}

\author{
Authors: \\ Kreshona Pillay ${ }^{1}$ \\ Johanna H. Buitendach ${ }^{1}$ \\ Herbert Kanengoni ${ }^{1,2}$ \\ Affiliations: \\ ${ }^{1}$ Department of Psychology, \\ University of KwaZulu-Natal,
} South Africa

${ }^{2}$ Department of Industrial Psychology, University of the Free State, South Africa

Correspondence to:

Herbert Kanengoni

Email:

hkanengoni@gmail.com

Postal address:

Private Bag X13,

Phuthaditjhaba 9866,

South Africa

Dates:

Received: 09 Oct. 2013

Accepted: 03 June 2014

Published: 11 Dec. 2014

How to cite this article: Pillay, K., Buitendach, J.H., \& Kanengoni, H. (2014). Psychological capital, job demands and organisational commitment of employees in a call centre in Durban, South Africa. SA Journal of Human Resource Management/ SA Tydskrif vir Menslike Hulpbronbestuur, 12(1), Art. \#599, 13 pages. http:// dx.doi.org/10.4102/sajhrm. v12i1.599

\section{Copyright:}

(C) 2014. The Authors. Licensee: AOSIS OpenJournals. This work is licensed under the Creative Commons Attribution License.
Orientation: The South African call centre industry is growing as call centres are increasingly used as a means of service delivery to customers. Positive psychologists posit that psychological capital could lead to positive outcomes such as organisational commitment of call centre staff.

Research purpose: This study investigated the relationship between psychological capital, job demands and organisational commitment and intended to determine whether psychological capital and job demands predict call centre employees' organisational commitment.

Motivation for the study: The study aimed to explore potential links between psychological capital, job demands and organisational commitment of call centre employees. It is premised on previous research that call centre job demands may be related to commitment to the organisation.

Research approach, design and method: This cross-sectional study sampled 117 call centre employees from Durban, South Africa, and used a biographical questionnaire, psychological capital questionnaire, the job-demands-resources scale and the organisational commitment questionnaire to collect data.

Main findings: Findings indicated a statistically significant relationship between psychological capital and work overload, as well as a practically and statistically significant relationship (medium effect) between psychological capital and continuance organisational commitment. The results showed that psychological capital has predictive value for continuance organisational commitment.

Practical/managerial implications: Psychological capital has predictive value for continuance organisational commitment. Organisations can develop initiatives to enhance positive psychological states and address this relationship.

Contribution: The findings could be beneficial to management and employees in considering ways to boost psychological capital in order to improve organisational commitment.

\section{Introduction}

The call centre industry in South Africa and around the world is growing at a rapid rate and has provided many job opportunities for South Africans with entry-level skills (Benner, 2006). Many organisations internationally, as well as in South Africa, use call centres as a means of service delivery to customers (Gordi, 2006) and therefore as the prevalence of call centres increases in organisations there is a subsequent need to understand the manner in which employees engage with work that is required of them in the call centre environment and to understand how they maintain their commitment to an organisation. Generally call centre work has been affiliated with work that requires a basic level of skill; however, despite this, the demands of call centre work can have an impact on the way in which employees view work and the organisation. The demands placed on call centre employees in relation to customer delivery may take a toll on employees and therefore may cause them to re-evaluate their commitment to the organisation. This is consistent with findings from previous studies (e.g. Holman, 2003), which have revealed that call centre work places high demands on employees. Malhotra and Mukherjee (2004) found a lack of organisational commitment amongst banking call centre employees. Call centre work involves optimising productivity and at the same time delivering exceptional customer service; therefore, it can be characterised as demanding and can often be stressful (Lewig \& Dollard, 2003). The choice of subjects for the study is built upon the nature of the call centre work environment, which is often characterised by, amongst others, emotion work, which mostly entails the need to consistently display positive emotional job-requirements (Ortiz-Bonnin, Garcia Buades, Caballer-Hernandez \& Zapf, 2013). In support, Holman (2003) adds that call centre work is often associated with high 
levels of stress, which is most likely caused by the various demands placed on call centre employees. The customer delivery demands that employees in a call centre are faced with may explain why there are low levels of organisational commitment in the call centre environment.

This article reports on a study conducted amongst call centre workers in Durban, South Africa (Pillay, 2012). The motivation for conducting the study is premised on previous findings regarding the nature of call centre work. Previous research suggests that the unpredictable demands of call centre work may be related to employee's commitment to an organisation (Armony \& Maglaras, 2004). In light of the increasing interest from researchers in positive psychology, such as the founders Seligman and Csikszentmihalyi (2000) as well as Money, Hillenbrand and Da Camara (2009), there is a need to find ways to help call centre employees to address these job demands and to do so by focusing on ways to enhance employees' positive psychological states and subsequently maintain employees' commitment to the organisation. Much of the research on psychological capital (PsyCap) (e.g. Avey, Luthans \& Jensen, 2009; Larson \& Luthans, 2006; Luthans, Norman, Avolio \& Avey, 2008), which is made up of the constructs hope, optimism, selfefficacy and resiliency, has been conducted internationally, whilst little research sampling call centre employees has been conducted in South Africa.

The central aim of this research is to investigate the relationship between psychological capital, job demands and organisational commitment. Although there has been a considerable amount of research conducted on call centre workers (e.g. Armony \& Maglaras, 2004; Benner, 2006; Lewig \& Dollard, 2003; Malhotra \& Mukherjee, 2004; Norman, 2005), little research addressing organisational commitment of call centre employees has been conducted in South Africa. In addition, despite the existence of numerous studies conducted on psychological capital in many different contexts (e.g. Avey, Luthans \& Jensen, 2009; Avey, Patera \& West, 2006; Larson \& Luthans, 2006; Luthans, Norman, Avolio \& Avey, 2008), there is limited research that addresses PsyCap issues in South African situations. With this in mind, there is a need to contribute to studies with practical implications on psychological capital in the South African context specifically. This study may provide a means for organisations to find ways to develop the psychological capital of their employees in order to achieve desirable organisational outcomes such as organisational commitment.

The study will therefore address the following research questions:

- What is the relationship between psychological capital, job demands and organisational commitment?

- To what extent do psychological capital and job demands predict organisational commitment?

- What is the relative contribution of each of the dimensions of psychological capital and job demands in predicting organisational commitment?

\section{Literature review}

Snyder and Lopez (2002) assert that the field of positive psychology is rapidly gaining interest in industrial psychology. Psychology as a discipline has predominantly focused on overcoming psychological or emotional problems (McMohan, 2009) and has tended to focus on negative aspects or experiences in individuals, thereby focusing on negative states as opposed to positive states (Seligman \& Csikszentmihalyi, 2000). Positive psychology aims to understand and foster factors that allow individuals to flourish (Seligman \& Csikszentmihalyi, 2000). It can be defined as the 'the study of human happiness: the conditions and processes that contribute to the flourishing or optimal functioning of people, groups, and institutions' (Gable \& Haidt, 2005, p. 104). 'Positive psychology promotes the role of positive emotions and individual strengths that are linked to successful outcomes' (McMohan, 2009, p. 64).

Compton (2005) posits that research conducted on positive psychology has shown that positive emotions and adaptive behaviour are specifically important in order to live a satisfying and productive life. Therefore, positive psychology is becoming a cutting edge trend in research as researchers and practitioners look for ways to enhance the efficiency of their delivery systems without jeopardising worker optimal quality. In this regard, the reasoning is that there is a need to focus more on developing and nurturing positive individual states as opposed to concentrating only on negative states. The emergence of positive psychology in the literature has resulted in the development of constructs reflecting positive psychological states in individuals, such as psychological capital.

PsyCap as a construct emerged from positive psychological literature and the study of positive organisational behaviour (POB) (Luthans, Avolio, Avey \& Norman, 2007). Luthans (2002b) defines POB as 'the study and application of positively oriented human resource strengths and psychological capacities that can be measured, developed, and effectively managed for performance improvement' (p. 59).

Avey, Nimnicht and Graber Pigeon (2009) posit that there has been a considerable amount of research paying specific attention to positive psychological capacities in the workplace. These psychological capacities include selfefficacy, hope, optimism and resilience. Self-efficacy refers to an individual's beliefs or perceptions about their ability to control certain situations and their confidence in performing specific tasks (Bandura, 1994). Hope is defined as 'a positive motivational state that is based on an interactively derived sense of successful (1) agency (goal-directed energy) and (2) pathways (planning to meet goals)' (Snyder, 2002, p. 250). Snyder (2002) argues that hope has two dimensions: willpower and pathways. Willpower refers to the motivation individuals have to achieve a desired goal (Luthans, Avey, Clapp-Smith \& Li, 2008), and pathways refer to alternative pathways to a goal, which aids individuals in achieving goals despite the presence of obstacles (Luthans, Avolio, Avey \& 
Norman, 2007). Optimism generally refers to having a positive outlook on life. Optimistic individuals expect good things to happen to them and in contrast pessimists expect bad things to happen to them (Scheier \& Carver, 1985). In relation to POB, Luthans (2002a) defines resilience as the capacity to rebound or bounce back from adversity, conflict, failure, or even positive events, progress, and increased responsibility (p. 702). These capacities are collectively referred to as psychological capital (Avey, Luthans \& Jensen, 2009).

Luthans, Youssef and Avolio (2007) define psychological capital as:

an individual's positive psychological state of development and is characterised by: (1) having confidence (self-efficacy) to take on and put in the necessary effort to succeed at challenging tasks; (2) making a positive attribution (optimism) about succeeding now and in the future; (3) persevering toward goals and, when necessary, redirecting paths to goals (hope) in order to succeed; and (4) when beset by problems and adversity, sustaining and bouncing back and even beyond (resilience) to attain success. (p. 3)

Research on PsyCap has shown growing evidence that PsyCap is significantly related to desired employee behaviours, attitudes and performance. Research has also found a significant relationship between PsyCap and job satisfaction and PsyCap and organisational commitment (Larson \& Luthans, 2006). Furthermore, studies by Avey, Wernsing and Luthans (2008) have found that employees' PsyCap is related to their positive emotions which in turn is related to their attitudes and behaviours relevant to organisational change. Studies on the PsyCap of Chinese workers show that PsyCap is related to their performance (Luthans, Avolio, Walumbwa \& Li, 2005; Luthans, Avey, Clapp-Smith \& Li, 2008). Currently there is little research that has been conducted on PsyCap in the South African context; more specifically, no research has been conducted on the PsyCap of call centre employees. Therefore, this research aims to address this disparity in the literature.

In relation to the research problem and the evidence provided by research on the construct, the PsyCap of call centre employees may therefore have an impact on employees' commitment to the organisation. PsyCap is recognised as a positive psychological state that can be further developed by the individual (Luthans, Avolio, Avey \& Norman, 2007, p. 543). If employees have confidence in themselves and put in effort to succeed in challenging tasks (self-efficacy), they may be able to deal with job demands such as meeting deadlines. If they are optimistic about their future (optimism) and persevere to attain goals (hope), as well as not allowing obstacles to stand in the way of success (resilience), they may be able to deal with the demands placed on them and therefore remain committed to their jobs. PsyCap with regard to this study is defined as individuals possessing positive psychological states (self-efficacy, optimism, hope and resilience) that may predict organisational commitment.

Research has shown that psychological capital is related to desired outcomes such as organisational commitment
(Larson \& Luthans, 2006). When individuals are optimistic about their futures in the organisation they remain committed to their jobs; individuals with self-efficacy believe they have control over their lives and can make a contribution to the organisation (Larson \& Luthans, 2006). Individuals with hope feel that they have the motivation to succeed in any tasks that they have to perform in the organisation; in relation to this, individuals with resilience are able to perform well in the organisation even in the face of adversity (Luthans, 2002b). As a result individuals are able to remain committed to the organisation. Therefore, the study aims to determine the relationship between PsyCap and organisational commitment of call centre employees.

No research has been conducted on the relationship between PsyCap and job demands; thus, this is a gap in the literature that this research aims to address. Job demands as a construct has been defined throughout literature by Karasek's (1979) job-demands-control model. Karasek posits that job demands are measured by determining 'psychological stressors involved in accomplishing the workload, stressors related to unexpected tasks, and stressors of job-related personal conflict' $^{\prime}$ (p. 291). Extensions and modifications to the model have resulted in other job demands models emerging.

The job-demands-resources model (JD-R) by Demerouti, Bakker, Nachreiner and Schaufeli (2001) attributes employee well-being to characteristics of work environments. Working environments can be characterised into two categories: job demands and job resources. 'Job demands refer to physical, social, or organisational aspects of the job that require sustained physical or mental effort and are therefore associated with certain physiological and psychological costs' (Demerouti et al., 2001, p. 501) and can include factors such as workload or time pressures. Job resources refer to physical, psychological, social or organisational aspects of the job that may play a functional role in aiding individuals to achieve work goals, reduce job demands and fuel personal growth and development (Demerouti et al., 2001). These researchers identify organisational resources as including job control, potential for qualification, participation in decision-making and task variety; social resources involve the support given by family, colleagues and peers (Demerouti et al., 2001). The model posits that extreme job demands may lead to exhaustion and that a lack of resources results in individuals not meeting job demands; this may lead to withdrawal from work and disengagement from work (Demerouti et al., 2001). Bakker, Demerouti and Schaufeli (2003) state that when employees are faced with demanding work conditions, those who have more resources at their disposal are more capable of dealing effectively with these demands.

Cavanaugh, Boswell, Roehling and Boudreau (2000) make a further distinction by separating job demands into job hindrances and job challenges. Job hindrances refer to work characteristics such as role ambiguity, job insecurity, constraints and interpersonal conflicts and job challenges refer to workload, time pressure and cognitive demands 
(Cavanaugh et al., 2000). Job hindrances are more likely to 'elicit negative emotions that interfere with employee's work goal achievement and well-being' (Van Den Broeck, De Cuyper, De Witte \& Vansteenkiste, 2010, p. 737) and although job challenges may be 'energy-depleting' (Van Den Broeck et al., 2010, p. 737), they are also stimulating and therefore provide employees with the challenge to achieve their goals. Most of the current literature focuses on the negative aspects of job demands and neglects to see that there is a positive component (i.e. job challenges).

Bakker et al. (2003) conducted a study with a sample of employees in a call centre and applied the JD-R model. Their study showed that job demands (work pressure, computer problems, emotional demands and changes in tasks) were important predictors of health problems and absenteeism and that job resources (e.g. social support, supervisory coaching, performance feedback and time control) were predictors of involvement, which is closely related to organisational commitment. However, in this study, the focus was only on the job demands aspect of the JD-R model. The reasoning was that work pressure, emotional demands and changes in tasks may be a more debilitating factor than lack of job resources in the call centre environment.

In light of the proposed study problem, job demands can be defined as psychological, social and organisational factors that impact negatively on an individual. The negative impact that job demands may have on an individual may further have an effect on an employee's commitment and dedication to the organisation. Norman (2005) identifies the following work-related exposures and demands placed on call centre staff:

work tasks and work quantity, call monitoring and logging, salary and additional numeration, physical exposures relate to comfort, time spent seated, continuous computer work, psychological demands such as emotional and cognitive demands, decision latitude, and support from colleagues and supervisors. (p. 5)

This study therefore aims to determine whether PsyCap and job demands predict organisational commitment.

Becker (1960) defines 'commitment' as a term used to describe 'consistent behaviour' (p. 33). According to Becker, this behaviour 'persists over a period of time and the person remains in the organisation' (p. 33). Subsequent studies have resulted in researchers beginning to identify other forms of commitment (Meyer, Stanley, Herscovitch \& Topolnytsky, 2002). Meyer and Allen (1984) make a distinction between affective commitment and continuance commitment. Affective commitment refers to 'an emotional attachment to, identification with, and involvement in the organisation' and continuance commitment refers to the 'perceived costs associated with leaving the organisation' (Allen \& Meyer, 1990). Allen and Meyer (1990) propose a third component of organisational commitment, normative commitment, which 'reflects a perceived obligation to remain in the organisation' (Meyer et al., 2002, p. 21). Allen and Meyer posit that employees with strong affective commitment remain because they want to, those with strong continuance commitment because they need to and those with strong normative commitment because they feel they ought to do so. An individual may experience the three components of commitment to varying degrees. In addition, the three components develop independently of each other as a result of different experiences or antecedents.

Similar arguments are raised by Powell and Meyer (2004), who further emphasise that the three components often develop in different ways and have different implications for job behaviour. Meyer et al. (2002) define a committed employee as being one who 'stays with an organisation, attends work regularly, puts in a full day and more, protects corporate assets, and believes in the organisational goals' (p. 22). In addition, Meyer et al. also conducted a meta-analysis, which revealed three forms of commitment that are related to each other yet distinguishable from one another. Affective and continuance commitment correlated with antecedents such as personal characteristics and work experiences, and personal characteristics, alternatives and investments, respectively (Meyer et al., 2002). The study also concluded that affective commitment 'had the strongest and most favourable correlations with organisationrelevant (attendance, performance, and organisational citizen behaviour) and employee-relevant (stress, workfamily conflict) outcomes' (Meyer et al., 2002, p. 20). Stander and Rothmann (2009) found that there were only two components of organisational commitment, namely attitudinal commitment and continuance commitment. The researchers found that affective commitment and normative commitment could be included as one component called attitudinal commitment. Meyer, Allen and Smith (1993) state that continuance commitment refers to employees' behavioural orientation, whereas normative and affective commitment refers to employees' attitudinal orientation.

A study on the impact of organisational commitment and organisational citizenship behaviour on turnover intentions of call centre personnel in Pakistan showed that 'turnover intentions of call centre personnel depended on the organisational commitment of the employees' (Ahmad, Shahzad, Rehman, Khan \& Shad, 2010, p. 585). The demanding nature of call centre work may make employees apathetic towards their work. The characteristics of the job have the potential to make employees unwilling to remain in an organisation that may not provide them with a sense of fulfilment and accomplishment. Employees may also feel as though they play a very insignificant role in the organisation, and in most cases there is little opportunity for promotion. The low skill nature of call centre work may make employees feel inferior to other employees in the organisation, and they may feel as though they are not making a valuable contribution to the organisation. $\mathrm{Hu}$ and Schaufeli (2011) conducted a study using the job-demands-resources model on Chinese business workers. They found that if individuals had job resources to deal with job demands, this contributed to them being able to cope effectively with the imminent 
demands and therefore maintain their commitment to the organisation. When individuals are faced with excessive job demands and feel as though they do not have the resources to the deal with these demands, this may have an impact on their decision to remain in an organisation: they may feel as though they do not belong in an organisation and cannot deal with the demands of the job. Wu and Norman (2006) found that organisational commitment and job demands often have an inverse relationship: when job demands increase organisational commitment often decreases. Hansez and Chmiel (2010) found that when commitment levels of management decreased, this was usually a result of increased job demands. This study therefore aimed to determine the relationship between job demands and organisational commitment.

The theoretical framework underpinning the research is Fredrickson's (2001) broaden-and-build theory of positive emotions. Positive psychology posits that positive emotions lead to optimal well-being (Fredrickson, 2001). She states that positive emotions signal and produce flourishing, not only in the present, but in the long term as well. Positive emotions are therefore 'worth cultivating, not just as end states in themselves but also as a means to achieving psychological growth and improved well-being over time' (Fredrickson, 2001, p. 220). Fredrickson's broaden-and build theory further explains the role of positive emotions:

The theory states that certain discrete positive emotions, including joy, interest, contentment, pride, and love, all share the ability to broaden people's momentary thought-action repertoires and build enduring personal resources, ranging from physical and intellectual resources to social and psychological resources. (Fredrickson, 2001, p. 219)

Positive emotions have the ability to widen the range of thoughts and actions that come to mind (Fredrickson, 2001). Fredrickson (2001) states that:

\begin{abstract}
joy creates the urge to play, push limits, and be creative; interest creates the urge to explore and to take in new information and experiences; contentment creates the urge to value current life circumstances and from new views of the self and the world; pride follows personal achievements and creates the urge to share news of achievements and envision greater achievements in the future. (p. 220)
\end{abstract}

Finally, love is considered to be a combination of joy, interest and contentment (Fredrickson, 2001).

Broadening modes of thinking and acting further 'builds enduring personal resources which function as reserves to be drawn on to manage threats' (Fredrickson, 2001, p. 220). Research and evidence gathered from previous studies has stated that positive emotions may fuel resilience. Resilience is considered to be a personal resource (Fredrickson, 2001). Optimism, self-efficacy, and hope can also be considered to be personal resources that may help individuals deal with adverse situations. Positive emotions may also fuel the development of these constructs and the overall psychological capital of an individual. The premise is that positive emotions may therefore enable call centre staff to deal with demands of the job, and the manner in which these emotions broaden action and thought repertoires may help to enhance an individual's well-being and lead to employees being committed to the job. Research on the role of positive emotions needs to be conducted in the South African context and this study aims to contribute to this gap in the research. Therefore, in light of the points raised in literature, the study firstly established the relationship between psychological capital, job demands and organisational commitment. Secondly, the researchers investigated the extent to which psychological capital and job demands predict organisational commitment. It is the belief of the researchers that the additive contributions of the findings have useful practical implications for situations in South African call centre environments.

\section{Method \\ Research participants}

Non-probability purposive sampling was used in the study to select the sample. Non-probability sampling refers to a sampling method where the selection of elements is not determined by the statistical element of randomness (Durheim \& Painter, 2006). In purposive sampling 'sampling depends not only on the availability and willingness to participate, but that cases that are typical to the population are selected' (Durheim \& Painter, 2006, p. 139). Non-probability purposive sampling was the most appropriate method to use as participants that were selected were employees that worked specifically within the call centre environment.

The call centre in Durban has approximately 150 staff members, including call centre representatives, call centre support staff, managers and senior managers. One hundred and seventeen participants completed the questionnaires. The sample comprised of more women $(81.2 \%)$ than men $(18.8 \%)$. The majority of the participants were in the age group 21-30 years old (42.7\%) followed by the participants between 17-20 years and those older than 51 years, which constituted $35.9 \%$ each. About $16 \%$ were between the ages of 31 and 40 years and only $5.1 \%$ of the participants were between 41 and 50 years. The racial demographics of the group is interesting to note as the majority of the participants were Indian and African and the minority of the participants were mixed race or white. Of the sample, most participants only had a matric qualification, $30.7 \%$ had a diploma and only 3.5\% had obtained degrees. The majority of the participants had been working for the organisation for more than 5 years $(62.4 \%)$. The majority of the respondents were non-management employees (93.2\%). Some of the categories had missing data. The demographic characteristics of the respondents are illustrated in Table 1.

\section{Measuring instruments}

The data collection method for the study consisted of the use of three scales and one biographical questionnaire that was developed by the researcher. The biographical questionnaire was only used in the study to collect demographic information about the participants in the study. Information was 
TABLE 1: Demographic characteristics of the participants.

\begin{tabular}{|c|c|c|c|}
\hline Variable & Participant characteristics & Frequency & $\%$ \\
\hline \multirow[t]{2}{*}{ Gender } & Male & 22 & 18.8 \\
\hline & Female & 95 & 81.2 \\
\hline \multirow[t]{5}{*}{ Age group } & $17-20$ & 42 & 35.9 \\
\hline & $21-30$ & 50 & 42.7 \\
\hline & $31-40$ & 19 & 16.2 \\
\hline & $41-50$ & 6 & 5.1 \\
\hline & Older than 51 & 42 & 35.9 \\
\hline \multirow[t]{4}{*}{ Race } & African & 28 & 24.1 \\
\hline & Indian & 71 & 61.2 \\
\hline & Mixed race & 13 & 11.2 \\
\hline & White & 4 & 3.4 \\
\hline \multirow[t]{4}{*}{ Qualification } & Matric & 75 & 65.8 \\
\hline & Diploma & 35 & 30.7 \\
\hline & Degree & 4 & 3.5 \\
\hline & Postgraduate degree & 0 & 0.0 \\
\hline \multirow{3}{*}{$\begin{array}{l}\text { Years working at the } \\
\text { organisation }\end{array}$} & 1 year & 4 & 3.4 \\
\hline & $2-5$ years & 40 & 34.2 \\
\hline & More than 5 years & 73 & 62.4 \\
\hline \multirow[t]{3}{*}{ Job level } & Non-management & 109 & 93.2 \\
\hline & Management & 7 & 6.0 \\
\hline & Senior management & 1 & 0.9 \\
\hline
\end{tabular}

collected on the participants' gender, age group, race, highest qualification, number of years working for the organisation, and the participant's job level in the organisation.

\section{The psychological capital questionnaire}

The psychological capital questionnaire (PCQ) was developed by Luthans, Avolio, Avey and Norman (2007) and was used as the measure for PsyCap. The PCQ consists of 24 items and four subscales measuring self-efficacy, hope, resilience and optimism. There are six items for each of the four subscales. An example of a self-efficacy item is 'I feel comfortable contributing to discussions about the companies strategies'; a hope item is 'If I find myself in a jam, I could think of ways to get out of it'; an example of a resilience item is 'I usually take stressful things at work in stride'; an example of a optimism item is 'I always look on the bright side of things regarding my job'. The responses are measured using a six-point Likert scale ranging from 1 (strongly disagree) to 6 (strongly agree). Avey et al. (2006) found a very high Cronbach's alpha coefficient of 0.90 for PsyCap and the Cronbach's alpha reliabilities of the four subscales were found to be $0.82,0.81,0.78$ and 0.65 .

\section{The job-demands-resources scale}

The job-demands-resources scale (JDRS) was developed by Jackson and Rothmann (2005) to measure job demands and resources. The scale consists of 42 items and responses are measured on a four-point Likert scale ranging from 1 (never) to 4 (always). According to Jackson and Rothmann, the JDRS has seven dimensions: organisational support, growth opportunities, overload, job insecurity, relationship with colleagues, control and rewards. Alpha coefficients for the above seven dimensions of the JDRS were $0.88,0.80$, 0.75, 0.90, 0.76, 0.71 and 0.78 (Jackson \& Rothmann, 2005). An example of an organisational support subscale item is 'Do you get on well with your colleagues?'; an example of a growth opportunities item is 'Does your job offer you opportunities for personal growth and development?'; an example of an advancement item is 'Does your job give you the opportunity to be promoted?'; an example of an overload item is 'Do you have too much work to do?'; an example of a job insecurity item is 'Do you need to be more secure that you will still be working in one year's time?' Rothmann, Mostert and Strydom (2006) found Cronbach's alpha reliabilities of between 0.76 and 0.92 for the JDRS. These results show that the JDRS has high levels of internal consistency.

\section{The organisational commitment questionnaire}

The organisational commitment questionnaire (OCQ) was developed by Allen and Meyer (1990) and consists of 18 items with three subscales measuring three components: affective, continuance and normative commitment. The responses are measured on a five-point Likert scale ranging from 1 (strongly disagree) to 5 (strongly agree). An example of an item in the affective organisational commitment subscale is 'I would be very happy to spend the rest of my career in the organisation'; an example of an item in the continuance organisational commitment subscale is 'It would be very hard for me to leave the organisation right now, even if I wanted to'; an item in the normative organisational commitment subscale is 'I do not feel any obligation to remain with my current employer'. Allen and Meyer found the Cronbach's alpha coefficient to be 0.87 for the subscale affective organisational commitment, 0.75 for continuance organisational commitment and 0.79 for normative organisational commitment. Meyer et al. (1993) found Cronbach's alpha coefficients for affective organisational commitment, continuance organisational commitment and normative organisational commitment to be $0.82,0.74$ and 0.83 , respectively. Nawab and Bhatti (2011) found a Cronbach's alpha reliability of more than 0.82 for the OCQ, which reflects a high internal consistency.

Cronbach's alpha reliabilities should be higher than 0.70 (Nunnally \& Bernstein, 1994), and considering that most researchers have found Cronbach's alpha reliabilities of over 0.70 for the three questionnaires, the questionnaires were used.

\section{Research design}

A quantitative research design was used to the conduct the research. Quantitative research involves counting and measuring events and performing the statistical analysis from numerical data (Howitt \& Cramer, 2003). Quantitative research refers to a data collection process in which the researcher moves deductively from abstract ideas, to specific data collection techniques, to precise numerical information produced by the techniques' (Neuman, 2006, p. 181). This design was favoured because the researcher aimed to determine the relationship between psychological capital, job demands and organisational commitment; thus the researchers believed that quantitative research was the 
most appropriate research design to use. A cross-sectional research design was used which refers to a:

a criterion groups design in which the different criterion groups are typically comprised of different age groups which are examined in terms of one or more variables at approximately the same time. (Huysamen, 1994, p. 98).

The sample was drawn from the population at a specific time and point (Huysamen, 1994), as opposed to taking multiple measures over an extended time period.

\section{Research procedure}

A letter of informed consent was given to the organisation asking for permission to conduct the research. A meeting was then set up with an employee from the human resources department to discuss the objectives of the research. The organisation gave permission to the researcher to conduct the research and to distribute questionnaires to the call centre employees during a 2-week period. Call centre employees were asked to participate in the study on a voluntary basis, and this was facilitated by employees in the human resources department who agreed to assist the researcher. Employees who were willing to participate in the study were given a letter to brief them on the description of the study, the purpose of the study, the procedure of participation in the study and issues of confidentiality and anonymity. They were also given an informed consent form before participation in the study. The collection of data took place over a period of 2 weeks as agreed with the organisation. This allowed participants enough time to complete questionnaires at their convenience. The human resource employees were provided with the questionnaires and distributed them amongst their staff. The collection of the questionnaires was done by the human resources employees; this ensured that questionnaires that were completed were collected at the end of the procedure.

\section{Statistical analysis}

Data was analysed using the SPSS statistical programme, version 21. Descriptive statistics were analysed by determining minimum and maximum scores, standard deviations and means. Skewness was evaluated to determine the symmetry of the distribution, and kurtosis was analysed to determine the peakedness of the distribution. Cronbach's alpha reliabilities were analysed to determine the internal consistency and reliability of the questionnaires.

Exploratory factor analysis was conducted to investigate construct validity. 'Factor analysis is a specialised statistical technique that is particularly useful for investigating construct validity' (Gregory, 2007, p. 135). Before exploratory factor analysis was conducted on the PCQ, items 13, 20 and 23 were reversed. On the OCQ items 3, 7, 10 and 16 were reversed. Factor analysis was conducted on the PCQ, JDRS and the OCQ to determine the underlying factors in the scales. The PCQ consists of four subscales, the JDRS consists of seven subscales, and the OCQ consists of three subscales. It was therefore necessary to determine what factors or subscales best represented the data in the study. The analysis of constructs aims to determine whether the constructs are homogenous and are therefore able to measure a single construct (Gregory, 2007). Cronbach's alpha coefficients were calculated to ascertain internal consistency of the measuring instruments (Gregory, 2007). According to Nunnally and Bernstein (1994), Cronbach's alpha coefficients should be higher than 0.70 to be considered to have an acceptable level of internal consistency.

Inferential statistics were used to analyse the data as inferences were made about a population from a sample. Pearson correlation coefficient analysis was used to determine the relationship between psychological capital, job demands and organisational commitment. Practically and statistically significant relationships were assessed. Practically significant relationships were assessed to determine 'whether a relationship is large enough to be important' (Steyn, 2002, p. 10). The following guidelines according to Cohen (2007) were used to determine whether a relationship is important: values of 0.3 to 0.49 indicate a medium effect and 0.5 to 0.99 indicate a large effect. A simple linear regression analysis was conducted to determine whether psychological capital had predictive value for organisational commitment. Standard multiple regression analysis was conducted to determine the relative contribution of the dimensions of psychological capital and job demands on organisational commitment.

\section{Results}

Exploratory factor analysis (EFA) was conducted on 24 items of the PCQ, 18 items of the OCQ and 42 items of the JDRS. Confirmatory factory analysis (CFA) would have been conducted but given the common problems associated with using CFA with small sample sizes and the fact that little research has been conducted in the area with the subjects used in this study, EFA was favoured. The choice of EFA was prompted by the fact that the study used a small sample of 117 employees and is designed to make an additive contribution to the body of literature (on PsyCap, job demands and organisational commitment in call centre environments) useful for those refining future research in the area. As such, this is an exploratory, investigative work from which tentative developments can be deduced rather than conclusive trends. Larger multi-site investigations are needed to confirm these results before firm conclusions can be made about South African situations at large.

Subjected to the principal component analysis, 24 items of the PCQ revealed that one factor emerged from the data (see Table 2). The Keizer-Meyer-Olkin value was 0.77 , which exceeds the threshold value of 0.6, and the Bartlett's test of sphericity showed a statistical significance. A two-component solution explained a total of $41.5 \%$ of the variance. An oblimin rotated solution revealed strong loadings and many items substantially loading on one component. The subscales hope, optimism, resilience and self-efficacy all loaded on one factor, which explained $32.5 \%$ of the total variance. The factor was called PsyCap. Avey et al. (2006) and Larson and Luthans (2006) both found that each subscale loaded onto four factors thus presenting the uniqueness of each factor as a measurement of PsyCap. 
For the JDRS, the results of the factor analysis showed two factors emerging. Job resources loaded on one factor and job demands loaded on one factor. As highlighted, the study only focused on the factor job demands in the analysis as job resources were not included in the research questions of the study. The Keizer-Meyer-Olkin value was 0.71 and exceeded the recommended 0.6 value and the Bartlett's test of sphericity showed a statistical significance. A two-component solution explained a total of $35.7 \%$ of the variance, with component one contributing $24.1 \%$ of the total variance and the second component, which was called work overload, explaining $11.5 \%$ of the total variance. Whereas this study revealed two factors, Rothmann, Mostert and Strydom (2006) found that five factors emerged from their data; one of the factors was overload.

As illustrated in Table 2, the results of the factor analysis of the OCQ showed that a one factor emerged from the data. The factor was called continuance organisational commitment. The Keizer-Meyer-Olkin value was 0.77, exceeding the recommended value of 0.6, and the Bartlett's test of sphericity showed a statistical significance. A twocomponent analysis explained a total of $42.8 \%$ of the variance. A clear interpretation of the two was obtained through the rotated solution, which showed strong loadings of items on one component. The one factor explained $26.66 \%$ of the total variance. Allen and Meyer (1990) found that organisational commitment can be measured by three factors. Stander and Rothmann (2009) only found two factors. They called the factors affective commitment and attitudinal commitment.

TABLE 2: Initial eigenvalues for the total variances explained.

\begin{tabular}{llccc}
\hline Questionnaire & Component & \multicolumn{3}{c}{ Initial eigenvalues } \\
\cline { 3 - 5 } & & Total & \% of variance & Cumulative \% \\
\hline Organisational & 1 & 4.800 & 26.664 & 26.664 \\
commitment questionnaire & 2 & 2.921 & 16.230 & 42.894 \\
Psychological & 1 & 7.791 & 32.464 & 32.464 \\
capital questionnaire & 2 & 2.179 & 9.078 & 41.541 \\
Job-demands-resources & 1 & 10.142 & 24.148 & 24.148 \\
scale & 2 & 4.831 & 11.502 & 35.651 \\
\hline
\end{tabular}

Table 3 shows the descriptive statistics of the factors that were used in the study. The negative skewness values indicate that the distribution is negatively skewed. Therefore, most scores cluster around high scores on the distribution. The kurtosis values indicate that the distribution is relatively flat; this indicates that the scores are relatively spread out along the distribution. The skewness and kurtosis values indicate that the distribution is normally distributed. Cronbach's alpha coefficients were used to test reliability of the PsyCap questionnaire, JDRS and the OCQ. According to Nunnally and Bernstein (1994), Cronbach's alpha coefficients should be greater than or equal to 0.70 to be regarded as reliable and acceptable. Table 3 reports the Cronbach's alpha coefficients for the questionnaires and the factors. Cronbach's alpha reliability for the PCQ was 0.87 , for the JDRS was 0.89, and for the OCQ was 0.77. The Cronbach's alpha coefficient for PsyCap (factor) was found to be 0.91 . Work overload had a Cronbach's alpha coefficient of 0.76 . The Cronbach's alpha level for continuance organisational commitment was found to be 0.82 .

Table 4 shows the results of the Pearson correlation coefficient analysis. Pearson correlation coefficient analysis was used to determine the relationship between psychological capital (as measured by the PCQ), work overload (as measured by the JDRS) and continuance organisational commitment (as measured by the OCQ). PsyCap was found to have a statistically significant relationship with work overload $[r(117)=0.227 ; p<0.05]$. PsyCap demonstrated a practically and statistically significant relationship, $[r(117)=0.428$; $p<0.01$, medium effect] with continuance organisational commitment. As illustrated in Table 4, no relationship was found to exist between work overload and continuance organisational commitment $[r(117)=0.128 ; p>0.05]$.

Table 5 shows the results of the simple linear regression. Simple linear regression analysis was conducted to determine whether PsyCap has predictive value for continuance organisational commitment. A compound

TABLE 3: Descriptive statistics and reliability statistics for the scales.

\begin{tabular}{|c|c|c|c|c|c|c|c|}
\hline Variable & Minimum & Maximum & Mean & SD & Skewness & Kurtosis & $\alpha$ \\
\hline PsyCap total & 75 & 134 & 108.9 & 12.9 & -0.19 & -0.42 & 0.87 \\
\hline Job-demands-resources scale total & 83 & 153 & 122.8 & 15.5 & -0.06 & -0.20 & 0.89 \\
\hline $\begin{array}{l}\text { Organisational commitment } \\
\text { questionnaire total }\end{array}$ & 33 & 90 & 55.6 & 8.7 & 0.71 & 2.53 & 0.77 \\
\hline Work overload & 5 & 16 & 11.92 & 2.76 & -0.37 & -0.58 & 0.76 \\
\hline $\begin{array}{l}\text { Continuance organisational } \\
\text { commitment }\end{array}$ & 14 & 52 & 29.9 & 5.4 & -0.23 & -0.08 & 0.82 \\
\hline
\end{tabular}

PsyCap, psychological capital; SD, standard deviation; $\alpha$, Alpha.

TABLE 4: Correlations between psychological capital, work overload and continuance organisational commitment. Measuring instruments

\begin{tabular}{|c|c|c|c|c|c|c|}
\hline \multirow[t]{2}{*}{ Measuring instruments } & \multicolumn{2}{|c|}{ OCQ total } & \multicolumn{2}{|c|}{ Work overload } & \multicolumn{2}{|c|}{ JDRS total } \\
\hline & $\begin{array}{l}\text { Pearson } \\
\text { correlation }\end{array}$ & $\begin{array}{l}\text { Significance } \\
\text { (two-tailed) }\end{array}$ & $\begin{array}{l}\text { Pearson } \\
\text { correlation }\end{array}$ & $\begin{array}{l}\text { Significance } \\
\text { (two-tailed) }\end{array}$ & $\begin{array}{l}\text { Pearson } \\
\text { correlation }\end{array}$ & $\begin{array}{l}\text { Significance } \\
\text { (two-tailed) }\end{array}$ \\
\hline OCQ total & - & - & - & - & - & - \\
\hline JDRS total & $0.281^{*}$ & 0.013 & $0.218^{*}$ & 0.038 & - & - \\
\hline PsyCap total & $0.428^{* *}$ & 0.006 & $0.227^{*}$ & 0.028 & $0.385^{* * *}$ & 0.000 \\
\hline
\end{tabular}

$\mathrm{OCQ}$, organisational commitment questionnaire; JDRS, job-demands-resources scale; PsyCap, psychological capital.

${ }^{*}$, Statistical significance at $p \leq 0.05 ;{ }^{* *}$, Statistical significance at $p \leq 0.0 ; * * *$, Statistical significance at $p \leq 0.001$ 
score was used to represent PsyCap and Table 5 shows that PsyCap significantly predicts continuance organisational commitment $\left(R^{2}=183 ; F=21.27 ; p<0.01\right)$. No relationship was found to exist between work overload and continuance organisational commitment; therefore, a multiple regression analysis could not be conducted to determine whether work overload had predictive value for continuance organisational commitment.

Standard multiple regression was used to ascertain how well a set of specific dimensions (self-efficacy, hope, resilience, optimism, work overload and resources) of the independent variables (psychological capital and job demands) predicted continuance organisational commitment. The idea was to obtain information about the model as a whole (all subscales) and the main and unique contribution of each of the individual subscales. As shown in Table 6, the regression model accounted for $20.3 \%$ of the variance $\left(R^{2}=0.203\right.$; $F=2.722 ; p>0.01)$. A statistically significance for only one predictor was found to make unique contribution to continuance organisational commitment: hope $(\beta=0.384 ; t=2.415 ; p<0.05)$.

\section{Discussion}

Firstly, the current study assessed how the concepts PsyCap, job demands and organisational commitment were conceptualised in the literature. PsyCap can be defined as positive psychological states that include self-efficacy, optimism, resilience and hope. Organisational commitment is defined as an employee's willingness to remain in the organisation, willingness to put in effort to contribute to the goalsof theorganisationandfeeling as though they aremaking a valuable contribution to the organisation. Continuance organisational commitment refers to individuals' feelings about remaining in the organisation and their obligation to remain in the organisation. Individuals with strong continuance organisational commitment remain in the organisation because they feel they have to or need to. Job demands refers to psychological, social and organisational factors that impact negatively on an individual. Secondly, the study attempted to explore the relationship between
PsyCap, job demands and organisational commitment of employees in a call centre in Durban, South Africa. Lastly the study aimed to determine whether PsyCap and job demands could predict organisational commitment and to determine the relative contribution of the dimensions of PsyCap and job demands on organisational commitment. The importance of such a study lies in its ability to provide an understanding of the demands placed on call centre employees and to understand the relationship between PsyCap and commitment to the organisation.

EFA was conducted on the PCQ, JDRS and the OCQ. The results of the factor analysis of the PCQ showed that a onefactor model best fitted the data in the study; the factor was called PsyCap. PsyCap explained $32.5 \%$ of the total variance. All four dimensions of PsyCap loaded on one factor thereby showing that all four dimensions are able to measure the construct of PsyCap. Avey et al. (2006) and Larson and Luthans (2006) found that the four subscales of PsyCap loaded on four different factors, thus showing that although all four subscales can provide a measure for the construct PsyCap, all four subscales are unique and provide measures for their respective dimensions as well (Larson \& Luthans, 2006).

Results of the EFA of the JDRS showed one factor emerged from the data. The factor was referred to as work overload. Work overload explained $11.5 \%$ of the total variance. Jackson and Rothmann (2005) found seven factors for the JDRS, whereas Rothmann, Mostert and Strydom (2006) only found five factors. However, the researchers in this study found one factor, called overload, in their results.

EFA of the OCQ showed that one factor was most appropriate. The factor was continuance organisational commitment. Continuance organisational commitment explained $26.6 \%$ of the total variance. The results of the factor analysis show that employees' commitment to the organisation is mainly based on their need to remain in the

TABLE 5: Simple linear regression (psychological capital and continuance organisational commitment).

\begin{tabular}{|c|c|c|c|c|c|}
\hline Model & $F$ & $\beta$ & SE & $R^{2}$ & $p$ \\
\hline Variable & 21.27 & - & - & 0.183 & $0.000 * * *$ \\
\hline Constant & - & - & 4.946 & - & $0.001 * *$ \\
\hline PsyCap & - & 0.194 & 0.042 & - & $0.000 * * *$ \\
\hline
\end{tabular}

PsyCap, psychological capital; $\beta$, Beta; $F$, Frequency; SE, standard error; $R^{2}$, coefficient of determination; $p$, probability value.

, Statistical significance at $p \leq 0.05 ;{ }^{* *}$, Statistical significance at $p \leq 0.0 ;{ }^{* * *}$, Statistical significance at $p \leq 0.001$

TABLE 6: Coefficients showing the relative contribution of each of the dimensions of psychological capital and job demands in predicting organisational commitment.

\begin{tabular}{|c|c|c|c|c|c|}
\hline \multirow[t]{2}{*}{ Model } & \multicolumn{2}{|c|}{ Unstandardised coefficients } & \multirow{2}{*}{$\begin{array}{l}\text { Standardised } \\
\text { coefficients: } \beta\end{array}$} & \multirow[t]{2}{*}{$t$} & \multirow[t]{2}{*}{ Significance } \\
\hline & $b$ & Standard error & & & \\
\hline (Constant) & 42.557 & 10.310 & - & 4.128 & 0.000 \\
\hline Self-efficacy & -0.262 & 0.260 & -0.133 & -1.006 & 0.318 \\
\hline Hope & 0.833 & 0.345 & 0.384 & 2.415 & 0.019 \\
\hline Resilience & -0.327 & 0.408 & -0.128 & -0.802 & 0.426 \\
\hline Optimism & -0.563 & 0.394 & -0.213 & -1.430 & 0.158 \\
\hline Work overload & 0.615 & 0.392 & 0.182 & 1.571 & 0.121 \\
\hline Lack of resources & 0.184 & 0.099 & 0.242 & 1.861 & 0.067 \\
\hline
\end{tabular}

$\beta$, Beta; $t$ - $t$ test. 
organisation and not because they have an attachment to the organisation. Allen and Meyer (1990) propose that one can measure organisational commitment using a three-factor model. Cohen (2007), however, found that the constructs in organisational commitment often overlap. Further, Stander and Rothmann (2009) found that organisational commitment can be measured using two factors. They found that affective and normative organisational commitment can be considered as one factor, namely attitudinal organisational commitment, with the other factor being continuance organisational commitment. The researchers only found one factor in this study; this therefore shows that this is a grey area and further research needs to be conducted on the concept of organisational commitment to reconceptualise the construct and to determine how many subscales underlie the construct.

The descriptive statistics showed that the data was normally distributed. A Cronbach's alpha reliability analysis was carried out to determine the psychometric properties of the PCQ, the JDRS and the OCQ. Cronbach's alpha coefficients were used to estimate the reliability of all the measuring instruments used in the study. The findings showed that all the measuring instruments had a high internal consistency as all Cronbach's alpha reliabilities were larger than 0.70 , and were therefore considered to be acceptable following Nunnally and Berstein's (1994) guidelines.

Pearson $r$ correlation analysis was conducted to determine the relationship between the variables in the study. No research has been found on the relationship between these three constructs together; therefore, this is a gap in the literature that the researcher aimed to address. The findings showed that there is a statistically and practically significant relationship (medium effect) between PsyCap and continuance organisational commitment. The two variables were strongly correlated $[r(117)=0.428 ; p<0.01]$. Larson and Luthans (2006) found that PsyCap is significantly related to organisational commitment. The study suggests that employees remain in the organisation because they need to remain in the organisation. This is reflected in the findings that, when employees have high levels of PsyCap, their commitment to the organisation is also high.

PsyCap was found to have a statistically significant relationship to work overload $[r(117)=0.227 ; p<0.05]$. This means that when levels of work overload are high, the PsyCap of employees is also high. This relationship may be explained with reference to the theoretical framework underlying this study. According to broaden-and-build theory of positive emotions, certain positive emotions build enduring personal resources, which include physical, intellectual, social and psychological resources (Fredrickson, 2001). Positive emotions have been shown to fuel personal resources such as resilience. Self-efficacy, optimism and hope can also be considered to be personal resources. More specifically, they can be considered to be psychological resources, which can be drawn upon to help manage threats (Fredrickson, 2001) such as job demands. Therefore, when job demands increase, the PsyCap of employees may also increase.
The multiple regression analysis revealed interesting findings. The researchers were interested in comparing the unique contribution of each specific dimension of the independent variables to explaining the continuance organisational commitment. The largest beta coefficient was 0.384, which was for hope. This means that in this study, hope made the strongest and statistically significant unique contribution to explaining continuance organisational commitment $(\beta=0.384 ; t=2.415 ; p<0.05)$. The other predictors' beta values were slightly lower, indicating less of a unique contribution. Therefore, in light of the above, hope is an important psychological capacity in predicting continuous organisational commitment, more so than selfefficacy, optimism and resilience and other job-related characteristics. The results are partly consistent with Larson and Luthans's (2006) findings that PsyCap is significantly related to organisational commitment. The additional aspect is that this study further looked at individual contribution of the PsyCap dimensions with results indicating that, as long as employees believe that there are alternate ways to deal with problems and that they are actively pursuing their work goals (hope), they are more likely to have high continuance organisational commitment.

No relationship was found to exist between work overload and continuance organisational commitment. $\mathrm{Wu}$ and Norman (2006) found that organisational commitment and job demands often have an inverse relationship, in that when job demands increase, organisational commitment often decreases. Hu and Shaufeli (2011) suggested that when job demands were high commitment to the organisation diminished, but when individuals had the resources to cope with the demands, then their commitment to the organisation was higher. The findings therefore suggest that regardless of whether levels are high, work overload has no relationship to continuance organisational commitment. Hansez and Chmiel (2010) found that when commitment levels of management decreased this was usually a result of increased job demands. However, Holman (2003) found that call centre employees often also have to endure high job demands. Malhotra and Mukherjee (2004) note that call centre staff often have low levels of organisational commitment. The study suggests that employees remain in the organisation because they feel they the need to remain in the organisation and therefore work overload is not related to their decision to remain in the organisation. This is reflected in the fact that results show that $62.4 \%$ of the sample has been working in the organisation for more than 5 years.

Research has shown that positive psychological states lead to positive organisational outcomes such as organisational commitment. A positive relationship was found between PsyCap and continuance organisational commitment; this led the researcher to determine whether PsyCap has predictive value for organisational commitment. The results of the simple linear regression analysis showed that PsyCap had statistically significant predictive value for continuance organisational commitment $\left(R^{2}=183, F=21.27, p<0.01\right)$. 
This result was consistent with the findings of Larson and Luthans (2006), who found that PsyCap has predictive value for organisational commitment.

\section{Limitations of the study}

It should be noted that this study contains a few important limitations that will require attention in future studies. The study used a cross-sectional design in order to determine the relationships between the variables in the study. This design however does not determine causality between the variables. The study used non-probability purposive sampling in which only employees who worked in the call centre environment were included in the sample. This form of sampling may lack generalisability to other call centres in South Africa because the nature of the work in call centres in different sectors varies. The data collection method used in this study was a survey design and therefore the data collected was a result of self-reported questionnaires. This means that participants may have answered the questionnaires in a socially desirable manner and may not have given accurate responses that reflected their real opinions and feelings. This limitation could have been exacerbated in this study because the study procedure involved the distribution of questionnaires to the staff by human resource employees in the organisation.

\section{Recommendations for future research}

It is recommended that longitudinal studies should be conducted to determine causality as well as to determine the levels of PsyCap, job demands and organisational commitment at different times during the research course. No research has been conducted on these three constructs together; therefore, there is a need for research to link these constructs together as research has shown that call centre staff face high job demands and there is generally a lack of organisational commitment in the call centre industry (Holman, 2003; Malhotra \& Mukherjee, 2004). There is a need for more studies to be conducted on organisational commitment as there is still confusion surrounding how many subscales underlie the construct. This is a grey area in research that needs to be addressed. There is also a need to provide research on the role of PsyCap as a psychological resource that can be used in the workplace to deal with organisational threats in the absence of other resources. For future studies, it might also be necessary to examine and clarify the strength and causal direction of the relationship between the four dimensions of PsyCap and the variable in context. Large multi-site studies could be helpful for identifying potential underlying aspects and findings that can allow generalisations beyond our study population.

\section{Contribution of the study}

The study has contributed to the literature on positive psychology as well as to the literature on PsyCap, which is lacking in the South African context. Positive emotions and positive psychological states play an important role in the workplace as they lead to positive outcomes such as organisational commitment. The study has also attempted to identify problems that employees may have in remaining committed to the organisation. The findings of this study showed that work overload did not have a relationship with continuance organisational commitment, thereby suggesting that employees remain committed to the organisation regardless of their workload. The research has also attempted to understand the role of job demands in the call centre environment to help employees find ways to address these demands by focusing on ways to enhance the PsyCap of employees. The findings can be used by organisations to develop interventions that increase employee's psychological capital in order to achieve desirable organisational outcomes such as organisational commitment and to deal with job demands that call centre employees face. Interventions can be created to help employees develop their self-efficacy, hope, optimism and resilience capacities.

\section{Conclusion and implications}

In South Africa, call centres have provided many job opportunities, especially for people with low-level skills (Benner, 2006). As it is difficult to attain employment in South Africa without a higher qualification than a matric, many individuals rely on call centres as an opportunity to gain employment and receive an income. Given the findings, the research suggests that PsyCap may have a significant influence on continuance organisational commitment. More specifically it was found that the PsyCap dimension hope held predictive value for continuance organisational commitment. The findings in relation to continuance organisational commitment therefore suggest that employees within the call centre environment are likely to remain committed to the organisation based on their need to remain within the organisation. Furthermore, the findings suggest that when employees are motivated to reach their own desired goals despite the presence of obstacles, this is likely to predict continuance organisational commitment. There are various recommendations and managerial implications that are very crucial to these and other organisations. To management and organisations, the findings of this study point to the critical importance of developing the psychological capacities of employees, especially in environments such as the call centre environment where work pressure, emotional demands and changes in tasks are characteristics. In addition, it is particularly useful to encourage personal development amongst call centre workers as this is more likely to improve the coping abilities of workers as well as being flexible to ease the emotional demands experienced in call centre environments.

The study has attempted to fill the gap in literature in relation to PsyCap in the South African context and the PsyCap of call centre staff. Very little research has been conducted on the role of job demands and the relationship it has on employees' commitment to their organisation. The results of the study have provided interesting information on job demands and organisational commitment in the call centre environment in the South African context; the findings have suggested that even though job demands may be high in the organisation, 
this has no effect on whether employees remain committed to the organisation or not. The study also provided interesting information with regard to the relationship between PsyCap and job demands. The results suggest that PsyCap is related to job demands and according to Fredrickson's (2001) broadenand-build theory, positive emotions have been found to help with managing threats and dealing with problems. Therefore, when employees have high levels of self-efficacy, hope, optimism and resilience, they are able to manage job demands such as work overload.

\section{Acknowledgements}

The financial assistance of the National Research Foundation South Africa (NRF) towards this research is hereby acknowledged. Opinions expressed and conclusions arrived at are those of the authors and are not necessarily to be attributed to the NRF.

\section{Competing interests}

The authors declare that they have no financial or personal relationship(s) that may have inappropriately influenced them in writing this article.

\section{Authors' contributions}

K.P. (University of KwaZulu-Natal) was the main researcher and was responsible for conceiving ideas, conducting fieldwork, as well as writing up the article. J.H.B. (University of KwaZulu-Natal) supervised the research and made conceptual contributions to the study. H.K. (University of KwaZulu-Natal) conducted the statistical analysis, co-authored the results and discussion sections, as well as addressing the editor's and copy editor's concerns.

\section{References}

Ahmad, S., Shahzad, K., Rehman, S., Khan, A.M., \& Shad, I.K. (2010). Impact of organisational commitment and organisational citizenship behaviour on turnover intentions of call centre personnel in Pakistan. European Journal of Social Sciences, $17(4), 585-591$.

Allen, N.J., \& Meyer, J.P. (1990). The measurement and antecedents of affective continuance, and normative commitment to the organisation. Journal of Occupational Psychology, 63, 1-18. http://dx.doi.org/10.1111/j.2044-8325.1990. tb00506.x

Armony, M., \& Maglaras, C. (2004). Contact centres with a call-back option and real-time delay information. Operational Research, 52, 527-545. http://dx.doi org/10.1287/opre.1040.0123

Avey, J.B., Luthans, F., \& Jensen, S. (2009). Psychological capital: A positive resource for combating stress and turnover. Human Resource Management, 48, 677-693. http://dx.doi.org/10.1002/hrm.20294

Avey, J.B., Nimnicht, J.L., \& Graber Pigeon, N. (2009). Two field studies examining the association between positive psychological capital and employee performance. Leadership \& Organisation Developm
org/10.1108/01437731011056425

Avey, J.B., Patera, J.L., \& West, B.J. (2006). The implications of positive psychological capital on employee absenteeism. Journal of Leadership and Organisational capital on employee absenteeism. Journal of Leadership and Organis
Studies, 13(2), 42-60. http://dx.doi.org/10.1177/10717919070130020401

Avey, J.B., Wernsing, T.S., \& Luthans, F. (2008). Can positive employees help positive organisational change? Impact of psychological capital and emotions on relevant attitudes and behaviours. Journal of Applied Behavioural Science, 44, 48-70. http://dx.doi.org/10.1177/0021886307311470

Bakker, A.B., Demerouti, E., \& Schaufeli, W.B. (2003). Dual processes at work in a call centre: An application of the job demands resources model. European Journal of Work and Organisational Psychology, 12, 393-417. http://dx.doi. org/10.1080/13594320344000165

Bandura, A. (1994). Self-efficacy. In V.S. Ramachaudran (Ed.), Encyclopaedia of human behaviour (pp. 71-81). New York, NY: Academic Press.

Becker, H.S. (1960). Notes on the concept of commitment. American Journal of Sociology, 66, 32-42. http://dx.doi.org/10.1086/222820
Benner, C. (2006). South Africa on call: Information technology and labour market restructuring in South African call centres. Regional studies, 40(9), 1025-1040. $\mathrm{http}: / / \mathrm{dx}$.doi.org/10.1080/00343400600928293

Cavanaugh, M.A., Boswell, W.R., Roehling, M.V., \& Boudreau, J.W. (2000). An empirical examination of self-reported work stress among US managers. Journal of Applied Psychology, 85, 65-74. http://dx.doi.org/10.1037/0021-9010.85.1.65

Cohen, J. (2007). Commitment before and after: An evaluation and reconceptualisation of organisational commitment. Human Resource Management Review, 17, 336-354. http://dx.doi.org/10.1016/j.hrmr.2007.05.001

Compton, W.C. (2005). An introduction to positive psychology. USA: Thomson Wadsworth.

Demerouti, E., Bakker, A.B., Nachreiner, F., \& Schaufeli, W.B. (2001). The job demandsresources model of burnout. Journal of Applied Psychology, 86, 499-512. http://dx.doi.org/10.1037/0021-9010.86.3.499

Durheim, K., \& Painter, D. (2006). Collecting quantitative data. In M. Terre Blanche, K. Durheim \& D. Painter (Eds.), Research methods in practice: Applied methods for the social sciences (pp. 132-159). Cape Town, South Africa: UCT Press.

Fredrickson, B.L. (2001). The role of positive emotions in positive psychology: The broaden-and-build theory of positive emotions. American Psychologist, 56, 218-226. http://dx.doi.org/10.1037/0003-066X.56.3.218

Gable, S.L., \& Haidt, J. (2005). What (and why) is positive psychology? Review of General Psychology, 9, 103-110. http://dx.doi.org/10.1037/1089-2680.9.2.103

Gordi, R.M. (2006). Job satisfaction of call centre representatives. Retrieved March 20, 2011, from http://etd.uwc.ac.za/usrfiles/modules/etd/docs/ etd_init_8719_1175067659.pdf

Gregory, R.J. (2007). Psychological testing: History, principles, and applications. (5th edn.). Boston, MA: Pearson International Edition.

Hansez, I., \& Chmiel, N. (2010). Safety behaviour: Job demands, job resources, and perceived management commitment to safety. Journal of Occupational Health Psychology, 15(3), 267-278. http://dx.doi.org/10.1037/a0019528

Holman, D. (2003). Call centres. In D. Holman, T.D. Wall, C.W. Clegg, P. Sparrow, \& A. Howard (Eds.), The new workplace: A guide to the human impact of modern working practices (pp. 115-131). London, UK: John Wiley \& Sons.

Howitt, D., \& Cramer, D. (2003). An Introduction to statistics in psychology. (2nd edn.). London, UK: Prentice Hall.

Hu, H., \& Schaufeli, W.B. (2011). Job insecurity and remuneration in Chinese family owned business workers. Career Development International, 16(1), 6-19. http:// dx.doi.org/10.1108/13620431111107784

Huysamen, G.K. (1994). Methodology for the social and behavioural sciences. Pretoria, South Africa: Southern Book Publishers.

Jackson, L.T.B., \& Rothmann, S. (2005). Work-related well-being of educators in a district of the North West province. Perspectives in Education, 23, 107-122.

Karasek, R. (1979). Job demands, job decision latitude, and mental strain: Implications for job redesign. Administrative Science Quarterly, 24, 285-308. http://dx.doi. org/10.2307/2392498

Larson, M., \& Luthans, F. (2006). Potential added value of psychological capital in predicting work attitudes. Journal of Leadership and Organisational Studies, 13, 75-92. http://dx.doi.org/10.1177/10717919070130020601

Lewig, K.A., \& Dollard, M.F. (2003). Emotional dissonance, emotional exhaustion and job satisfaction in call centre workers. European Journal of Work and Organisational Psychology, 12, 366-392. http://dx.doi.org/10.1080/13594320344000200

Luthans, F. (2002a). The need for and meaning of positive organisational behaviour Journal of Organisational Behaviour, 3, 695-706. http://dx.doi.org/10.1002/ job.165

Luthans, F. (2002b). Positive organisational behaviour: Developing and managing psychological strengths. Academy of Management Executive, 16, 57-72. http:// dx.doi.org/10.5465/AME.2002.6640181

Luthans, F., Avey, J.B., Clapp-Smith, R., \& Li, W. (2008). More evidence on the value of Chinese workers psychological capital: A potentially unlimited competitive resource? The International Journal of Human Resource Management, 19 818-827. http://dx.doi.org/10.1080/09585190801991194

Luthans, F., Avolio, B.J., Avey, J.B., \& Norman, S.M. (2007). Positive psychological capital: Measurement and relationship with performance and satisfaction Personnel Psychology, 60, 541-572. http://dx.doi.org/10.1111/j. 1744-6570.2007.00083.x

Luthans, F., Avolio, B.J., Walumbwa, F., \& Li, W. (2005). The psychological capital of Chinese workers: Exploring the relationship with performance. Management and Organisation Review, 1, 247-269. http://dx.doi.org/10.1111/j. 1740-8784.2005.00011.x

Luthans, F., Norman, S.M., Avolio, B.J., \& Avey, J.B. (2008). Supportive climate and organisational success: The mediating role of psychological capital. Journal of Organisational Behavior, 29(2), 219-238. http://dx.doi.org/10.1002/job.507

Luthans, F., Youssef, C.M., \& Avolio, B.J. (2007). Psychological capital: Developing the human competitive edge. Oxford, UK: Oxford University Press.

McMohan, G. (2009). Positive feelings at work. Retrieved March 25, 2011, from http:// www.trainingjournal.com

Malhotra, N. \& Mukherjee, A. (2004). The relative influence of organisational commitment and job satisfaction on service quality of customer-contact employees in the banking call centres. The Journal of Service Marketing, 18(2/3) 162-174. http://dx.doi.org/10.1108/08876040410536477

Meyer, J.P., \& Allen, N.J. (1984). Testing the 'side-bet theory' of organisational commitment: Some methodological considerations. Journal of Applied Psychology, 69, 372-378. http://dx.doi.org/10.1037/0021-9010.69.3.372 
Meyer, J.P., Allen, N.J. \& Smith, C. (1993). Commitment to organisations and occupations: Extension and test of a three-component conceptualisation.
Journal of Applied Psychology, 87, 538-551. http://dx.doi.org/10.1037/ 0021-9010.78.4.538

Meyer, J.P., Stanley, D.J., Herscovitch, L., \& Topolnytsky, L. (2002). Affective, continuance, and normative commitment to the organisation: A Meta-analysis of antecedents, correlates, and consequences. Journal of Vocational Behaviour, 61 20-52. http://dx.doi.org/10.1006/jvbe.2001.1842

Money, K., Hillenbrand, C., \& Da Camara, N. (2009). Putting positive psychology to work in organisations. Journal of General Management, 34(3), 21-36.

Nawab, S., \& Bhatti, K.K. (2011). Influence of employee compensation on organisational committment and job satisfaction: A case study of educational sector of Pakistan. International Journal of Business and Social Science, 2(8), 25-32.

Neuman, W.L. (2006). Social research methods: Qualitative and quantitative approaches. London, UK: Sage Publications.

Norman, K. (2005). Call centre work: Characteristics, physical and psychosocial exposure and health related outcomes. Published doctoral thesis. Sweden: Department of Mechanical Engineering, Linkopings University.

Nunnally, J.C., \& Bernstein, J. (1994). Psychometric theory. New York, NY: McGraw Hill.

Ortiz-Bonnin, S., Garcia Buades, M.E., Caballer-Hernandez, A., \& Zapf, D. (2013). A multi-level analysis of the moderating role of supportive team climate in the emotion work-emotional exhaustion relationship. Poster presentation at the Sixteenth Congress of the European Association of Work and Organizational Psychology, Muenster, Germany, 22-25 May.

Pillay, K. (2012). Happiness, psychological capital and organisational citizenship behaviour of employees in a financial institution in Durban, South Africa. Unpublished master's thesis, School of Applied Human Sciences, University of KwaZulu-Natal, South Africa, viewed n.d., from http://researchspace.ukzn. ac.za/xmlui/bitstream/handle/10413/9379/Pillay_Kreshona_2012.pdf
Powell, M., \& Meyer, J.P. (2004). Side-bet theory and the three-component mode of organisational commitment. Journal of Vocational Behaviour, 65, 157-177. http://dx.doi.org/10.1016/S0001-8791(03)00050-2

Rothmann, S., Mostert, K., \& Strydom, M. (2006). A psychometric evaluation of the job demands-resources scale in South Africa. SA Journal of Industrial Psychology, 32(4), 76-86. http://dx.doi.org/10.4102/sajip.v32i4.239

Scheier, M., \& Carver, C. (1985). Optimism, coping, and health: Assessment and implications of generalized outcome expectancies. Health Psychology, 4 219-247. http://dx.doi.org/10.1037/0278-6133.4.3.219

Seligman, M.E.P., \& Csikszentmihalyi, M. (2000). Positive psychology: An introduction. American Psychologist, 55, 5-14. http://dx.doi.org/ 10.1037/0003-066X.55.1.5

Snyder, C.R. (2002). Hope theory: Rainbows in the mind. Psychological Inquiry, 13(4), 249-275. http://dx.doi.org/10.1207/S15327965PLI1304_01

Snyder, C.R., \& Lopez, S.J. (2002). The handbook of positive psychology. New York, NY: Oxford University Press.

Stander, M.W., \& Rothmann, S. (2009). The relationship between leadership, job satisfaction and organisational commitment. SA Journal of Human Resource Management, 7(3), 7-13.

Steyn, H.S. (2002). Practically significant relationships between two variables. SA Journal of Industrial Psychology, 28(3), 10-15.

Van den Broeck, A., De Cuyper, N., De Witte, H., \& Vansteenkiste, M. (2010). Not all job demands are equal: Differentiating job hindrances and job challenges in the job demands-resources model. European Journal of Work and Organisational Psychology, 19(6), 735-759. http://dx.doi.org/10.1080/13594320903223839

Wu, L., \& Norman, I.J. (2006). An investigation of job satisfaction, organizational commitment and role conflict and ambiguity in a sample of Chinese undergraduate nursing students. Nurse Education Today, 26(4), 304-314. http://dx.doi.org/10.1016/j.nedt.2005.10.011 